\title{
Impregnation of Cellulose Acetate Films with Carvacrol Using Supercritical Carbon Ioxide
}

\author{
TIJANA N. ADAMOVIĆ, University of Valladolid, Department of Chemical \\ Original scientific paper \\ Engineering and Environmental Technology, Valladolid, Spain UDC: 547.913 \\ STOJA L. MILOVANOVIĆ, University of Belgrade, DOI: 10.5937/tehnika1801017A
}

Faculty of Technology and Metallurgy, Belgrade

DARKA D. MARKOVIĆ, University of Belgrade,

Innovation Center of the Faculty of Technology and Metallurgy, Belgrade

IRENA T. ŽIŽOVIĆ, Wroclaw University of Science and Technology,

Faculty of Chemistry, Wroclaw, Poland

Cellulose acetate films were impregnated with carvacrol using supercritical carbon dioxide. The supercritical impregnation process, conducted in a static regime at pressure of $21 \mathrm{MPa}$ and temperature of $50{ }^{\circ} \mathrm{C}$, was optimized by variation in the processing time (30 and $120 \mathrm{~min}$ ) and decompression rate (from $0.3 \mathrm{MPa} / \mathrm{min}$ to $36 \mathrm{MPa} / \mathrm{min}$ ). Characterization of the obtained cellulose acetate films was performed by Atomic Force Microscopy and Differential Scanning Calorimetry. Effects of glycerol and carvacrol on the properties of the films were discussed. Release kinetics from the cellulose acetate film with $31.4 \%$ of carvacrol was investigated in a physiological saline solution. In addition, the Higuchi and Korsmeyer-Peppas release models fitted the carvacrol release curve well. Obtained cellulose acetate films impregnated with carvacrol can be of interest for the application in medicine as wound dressings considering their biocompatibility and biodegradability as well as their potential antimicrobial activity or in the food industry as an active food packaging.

Key words: carvacrol, cellulose acetate film, supercritical $\mathrm{CO}_{2}$, supercritical impregnation

\section{INTRODUCTION}

Environmental and economic concerns associated with solid waste accumulation and limitation of the resources led to global interest in biodegradable and renewable materials [1]. Considering that cellulose constitutes are the most abundant renewable biopolymers available, their application in different fields has gained much scientific attention $[1,2]$. Studies regarding cellulose are focused on cellulose derivates because they have better processability than the pure cellulose [1]. Among cellulosic derivates, cellulose acetate (CA) is of particular interest due to its versatility and broad applications from packaging materials and filters, to textiles [2]. In addition, it can be used in me-

Author's address: Tijana Adamović, University of Valladolid, Department of Chemical Engineering and Environmental Technology, Valladolid, Spain

e-mail: tijanaadamovic@gmail.com

Paper received: 13.01.2018.

Paper accepted: 07.02.2018. dicine for controlled release of active components due to its biocompatibility [3]. A number of reports have been published on utilization of CA fibers with antimicrobial substances for application as wound dressings [4, 5] as well as on CA films prepared by the solvent casting method intended to be used for food packaging $[1,6,7]$ with or without addition of antimicrobial substances. Antimicrobial active packaging can reduce the rate of microbial growth, increase the lag phase and/or inactivate microorganisms present in the target food or on the package itself [6]. Overproduction of antibiotics and their excessive use led to the appearance and spared of resistant bacterial strains [5]. Since a resistance of bacteria to plant extracts has never been recorded, plant extracts' constituents are nowadays again in the focus of scientific attention [5, 8]. One of the natural bioactive components that has shown promising results as bactericide is carvacrol [9, 10]. Carvacrol (5-isopropyl-2-methyl phenol) is a natural monotherpenic phenol found in isolates of Lamiaceae family (i.e. oregano, thyme) [9, 11-13]. It also displays anti-inflammatory and antioxidant activity [9, 
$11,12]$. Because carvacrol has been approved as a safe food additive by the US Food and Drug Administration (2006) and due to its beneficial biological activities, it can be used both in food packaging and in wound dressings [9, 11-13]. Since carvacrol is prone to degradation and rapid evaporation, it is important to find a suitable technique to prolong its activity $[9,12$, 13].

Increase in carvacrol's bioactivity and possibilities for its application can be achieved by its impregnation into appropriate carriers. Lilois et al. [9] reported increase in carvacrol's antimicrobial activity after its incorporation into liposomes. Significant antibacterial activity of carvacrol, even against methicillin resistant strains, was reported for carvacrol impregnated CA beads [10].

Conventional methods of incorporation of bioactive components into polymeric carriers have certain drawbacks such as excessive use of large quantities of organic solvents or high temperatures. These can be avoided by utilization of supercritical fluids that allow production of high purity materials free of residual solvents which can be used in the pharmaceutical and food industry [14, 15]. Impregnation using supercritical fluids implies dissolution of an active component into a supercritical fluid and contact of the resulting mixture with a polymer [14].

Active component can be entrapped by a simple deposition into the polymer matrix or by chemical interaction with the polymer. Supercritical carbon dioxide $\left(\mathrm{scCO}_{2}\right)$ has been proven as an advantageous medium for polymer processing [2, 15]. Besides having low critical pressure and temperature $(P \mathrm{c}=7.3$ $\mathrm{MPa}$ and $T \mathrm{c}=31.1{ }^{\circ} \mathrm{C}$ ), $\mathrm{scCO}_{2}$ is non-toxic, nonflammable, chemically inert, cheap, and easily available $[2,15]$. Physical properties of $\mathrm{scCO}_{2}$, such as low viscosity, high diffusivity and the absence of surface tension effects impart high penetrating capability to $\mathrm{scCO}_{2}$ together with good mass and heat transport properties $[2,14]$.

This study was focused on the environmentally friendly $\mathrm{scCO}_{2}$ impregnation of biodegradable $\mathrm{CA}$ films with a natural antimicrobial agent carvacrol. Obtained films were characterized regarding their topography and thermal properties. Release of carvacrol from the CA film was tested in a physiological saline solution.

\section{MATERIALS AND METHODS}

\subsection{Materials}

Cellulose acetate beads $(32.0 \%$ acetyl content, Eastman, Poland), acetone (Zorka, Serbia) and glycerol (purity 99\%, Galafarm, Macedonia) were used for the fabrication of films. The films were impregnated with carvacrol (purity $>99 \%$, Sigma-Aldrich, Germany) using carbon dioxide (purity 99\%, MesserTehnogas, Serbia).

\subsection{Methods}

\subsubsection{Preparation of cellulose acetate films}

CA films were prepared by the solvent casting method. The first type of film was prepared without glycerol as a plasticizer. CA beads $(1 \mathrm{~g})$ were dissolved in a mixture of acetone $(27 \mathrm{~mL})$ and distilled water $(3 \mathrm{~mL})$ by mixing during $2 \mathrm{~h}$ at room temperature. Obtained solution was poured onto a ceramic dish (dimensions $15.5 \mathrm{~cm} \times 7 \mathrm{~cm}$ ) and air dried for 7 days. In fabrication of the second type of film, the same procedure was repeated with addition of glycerol $(0.1 \mathrm{~g})$ to the $\mathrm{CA} /$ acetone/water solution.

\subsubsection{Supercritical impregnation of cellulose acetate films with carvacrol}

A high pressure view cell described elsewhere [16] was used for carvacrol impregnation into CA fil$\mathrm{ms}$. A film sample was placed in the cell above a glass container with carvacrol and separated by a fine mesh. Once the temperature of $50{ }^{\circ} \mathrm{C}$ was reached, $\mathrm{CO}_{2}$ was introduced in the cell and pressure was elevated to 21 MPa.

After 30 or 120 min of the impregnation, the $\mathrm{CO}_{2}$ was removed from the cell. Decompression rates were varied in the range from 0.3 to $36 \mathrm{MPa} / \mathrm{min}$. Impregnation yield was calculated as a ratio between the mass of impregnated carvacrol and the mass of impregnated film multiplied by $100 \%$.

\subsubsection{Characterization of cellulose acetate films}

CA films were analyzed by Atomic force micrscopy (AFM) using a microscope Quesant (Ambios Technology, USA) in oscillating mode. Measurements were performed in air atmosphere using $\mathrm{T}$-shaped silicone consoles with a $40 \mathrm{~N} / \mathrm{m}$ spring constant. All images were obtained at $1 \mathrm{~Hz}$, with $512 \times 512$ image resolution in different square areas.

Differential scanning calorimetry (DSC) analysis was performed with a calorimeter Seteram 151 equipped with softer SETSOFT 2000. All measurements were performed in a nitrogen atmosphere at temperatures ranging from 25 to $300{ }^{\circ} \mathrm{C}$ with a heating rate of $10{ }^{\circ} \mathrm{C} / \mathrm{min}$.

\subsubsection{Release kinetics}

Carvacrol release was investigated by immersion of the impregnated CA films in a physiological saline solution $(9 \mathrm{~g} / \mathrm{L})$ at $37{ }^{\circ} \mathrm{C}$ in a static conditions. At predetermined time intervals an aliquot $(5 \mathrm{~mL})$ of the solution was taken, analyzed and returned to the solution. Carvacrol's concentration was determined by measuring absorption intensity at $\lambda_{\max }=273 \mathrm{~nm}$ using 
an UV-VIS spectrophotometer Cary 100 Scan (Varian). In order to examine the release profile of carvacrol from CA films, following kinetics models were used:

$$
\begin{aligned}
& \text { Korsmeyer-Peppas: } \frac{M_{t}}{M_{\infty}}=k \cdot t^{n} \\
& \text { First-order: } \ln \left(1-\frac{M_{t}}{M_{\infty}}\right)=-k \cdot t \\
& \text { Higuchi: } \frac{M_{t}}{M_{\infty}}=k \cdot t^{1 / 2}
\end{aligned}
$$

where: $M_{t}$ is the amount of carvacrol released in any time $t, M_{\infty}$ is the amount of carvacrol released at infinite time, $k$ is the release rate constant, and $n$ is the release exponent.

\section{RESULTS}

\subsection{Effect of processing conditions on carvacrol}

In order to determine the effect of decompression rate on the impregnation yield of carvacrol in CA films without glycerol, initial impregnation experiments were performed at $21 \mathrm{MPa}$ and $50{ }^{\circ} \mathrm{C}$ for exposure times of 30 and $120 \mathrm{~min}$.

Results presented in Figure 1 revealed that the impregnation yield decreases with an increase in the decompression rate from 0.3 to $36 \mathrm{MPa} / \mathrm{min}$ for both operating times. Varona et al. [17] reported other trend i.e. that the linalool impregnation yield into starch increases with an increase in depressurization rate.

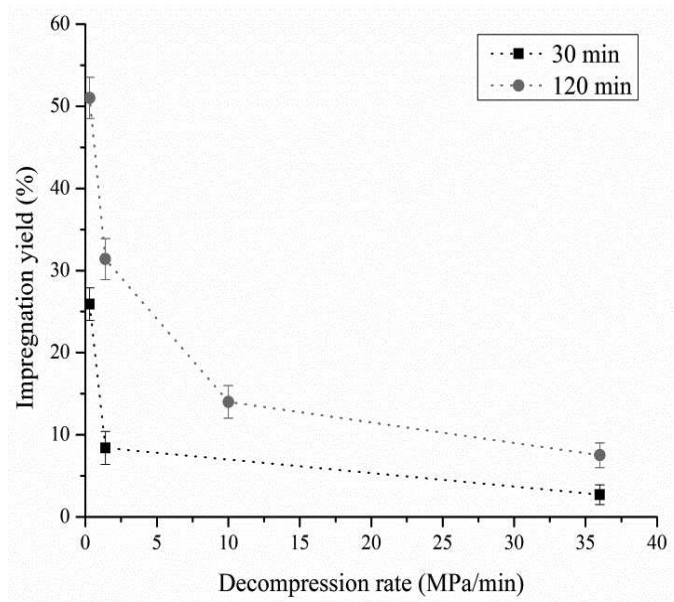

Figure 1 - Effect of decompression rate on impregnation yield

These results confirm that a process of impregnation is strongly dependent on the operating conditions employed as well as on the interaction between an impregnating substance and a polymer. It is postulated that the system with a low affinity between an impregnating substance and a polymer and high decompression rate achieves higher impregnation yields unlike the system with an intensive impregnating substance-polymer interaction where low decompression rate induces higher impregnation yields [18]. Hence, decompression rate of $1.4 \mathrm{MPa} / \mathrm{min}$ was chosen as the optimal considering impregnation yield and duration of decompression.

Figure 2 shows the influence of operating time and addition of glycerol on the impregnation yield of carvacrol. It can be seen that an increase in operating time increases the impregnation yield of carvacrol. The same trend was reported for impregnation of CA beads with thymol and carvacrol $[10,19]$. Shen et al. [20] showed that compounds with hydroxyl groups, impregnated using $\mathrm{scCO}_{2}$, had affinity towards hydrogen bonding sites of CA. The highest carvacrol impregnation yield obtained under the employed conditions was $31.4 \%$ for the CA film without glycerol. When carvacrol was impregnated into CA beads at $21 \mathrm{MPa}$ and $50{ }^{\circ} \mathrm{C}$ for $120 \mathrm{~min}$, the impregnation yield of $19.7 \%$ was obtained [10]. Therefore, the film morphology enables faster impregnation in comparison to the bead morphology. This is due to the larger outer surface exposed to supercritical fluid, shorter diffusion paths for sorbed molecules in the polymer and larger void fractions between the polymer chains in the case of films (due to the solvent evaporation in the solvent casting method).

When glycerol was added, the carvacrol impregnation yield decreased compared to films without glycerol. Although glycerol as a plasticizer should decrease interactions between polymeric chains, in this case we can presume that glycerol incorporates itself between polymeric chains and decreases diffusion rates of carvacrol in the polymer matrix.

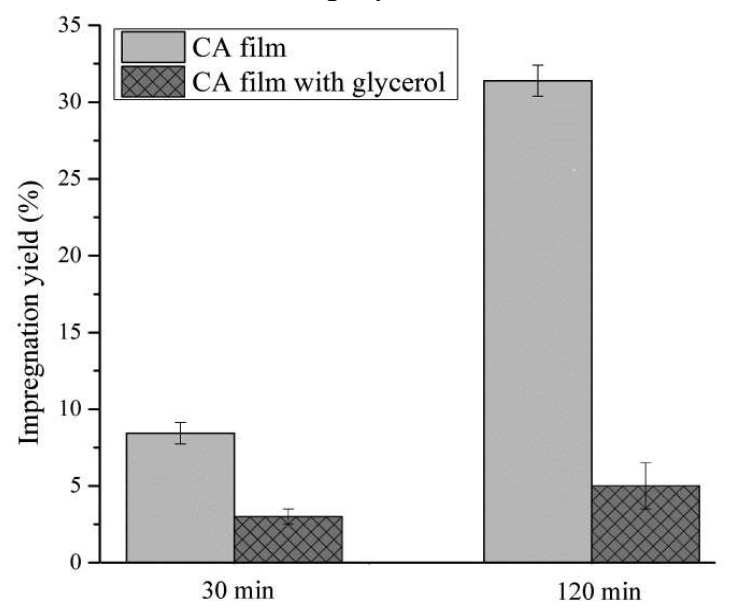

Figure 2 - Effect of operating time and addition of glycerol on impregnation yield

\subsection{Characterization of cellulose acetate films}

The first type of CA film (without glycerol) had thickness of $0.21 \pm 0.05 \mathrm{~mm}$, while the CA film with added glycerol had thickness of $0.26 \pm 0.04 \mathrm{~mm}$. Wongsasulak et al. reported [21] an increase in fiber 
diameter of zein films containing $10 \mathrm{wt} \%$ of glycerol compared to the film without glycerol.

AFM images revealed the presence of small bumps on the surface of the CA film without glycerol (Figure 3a) which was in accordance with the data reported in the literature $[3,6]$. The CA film with glycerol was shown to have some holes (Figure 3b). Yuan et al. [3] showed that water and a plasticizer in the solvent system for the CA film casting influenced the morphology and ultimately the properties of the films. Depending on their ratio, they increased or decreased the number and size of the holes onto and inside CA films.

a)

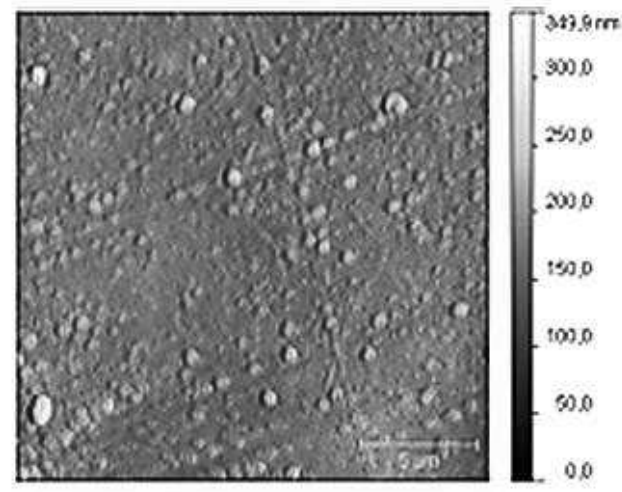

b)

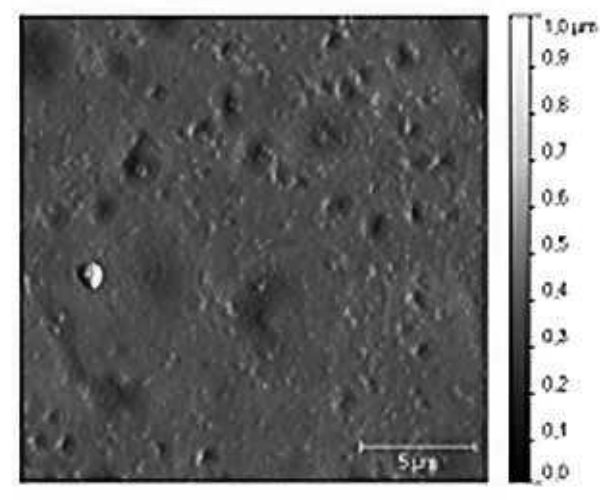

c)

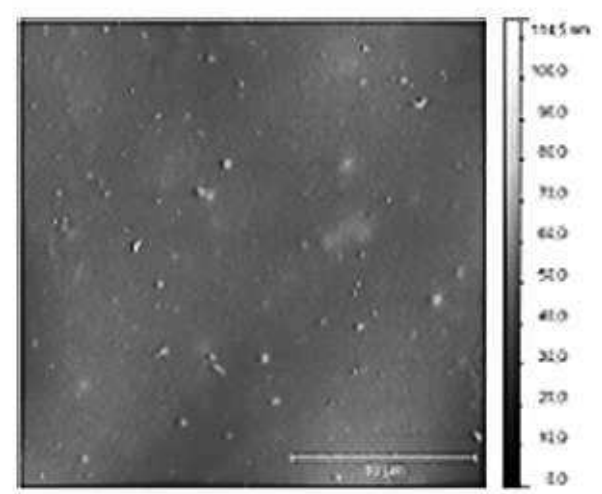

Figure 3 - AFM images of surface of: a) CA film, b) CA flim with glycerol, and c) CA film with carvacrol (31.4\%)

The CA film without glycerol impregnated with carvacrol (Figure 3c) is more homogenous with a smaller number of bumps on its surface compared to the first film. It was previously reported that pure $\mathrm{CO}_{2}$ doesn't affect CA because chains of CA are interconnected with hydrogen bonds and $\mathrm{CO}_{2}$ doesn't have enough solvent power to overcome this interactions $[19,20]$. So, we can assume that only carvacrol with its $\mathrm{OH}$ groups interacted with hydrogen bonds of CA enhancing the polymer chains' mobility and inducing slight changes in the film morphology.

DSC thermograms of the CA films without and with glycerol are presented in Figure 4a. The endotherms detected around $100{ }^{\circ} \mathrm{C}$ can be atributed to the removal of water from the sample [1, 19]. In the sample with glycerol this peak is less pronaunced and detected around $120^{\circ} \mathrm{C}$. The glass transition temperature of the films without and with glycerol was detected at $206.1^{\circ} \mathrm{C}$ and $236.7^{\circ} \mathrm{C}$, respectively. Given that results from the literature report decrease in the glass transition temperature of films due to the plasticizer adition $[3,21]$, the effect of glycerol on the CA films should be further investigated.

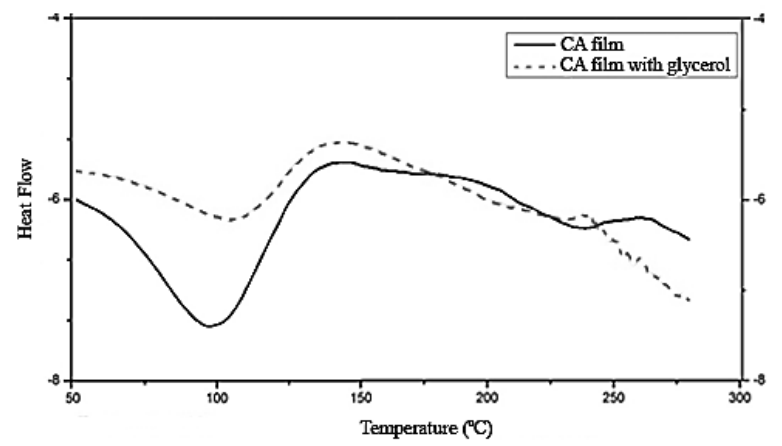

a)

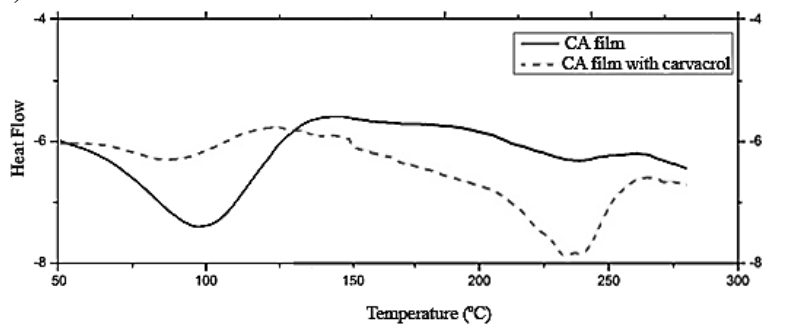

b)

Figure 4-DSC thermograms of: a) CA films without and with glycerol and b) CA films without and with carvacrol $(31.4 \%)$

DSC thermograms of the CA films (the first type, no glycerol added) neat and impregnated with carvacrol are presented in Figure 4b. In the sample with carvacrol, the endotherm around $100{ }^{\circ} \mathrm{C}$ attributed to the removal of water is less pronounced compared to the film without carvacrol. Also, impregnation of carvacrol led to the decrease of the glass transition temperature from $206.1{ }^{\circ} \mathrm{C}$ to $175.4^{\circ} \mathrm{C}$ confirming plasticizing effect of carvacrol on CA. Decrease in the glass transition temperature of CA beads for $25^{\circ} \mathrm{C}$ after thymol impregnation with yield of $13.7 \%$ was 
previously reported [19]. The endothermic peak in the temperature interval $232-240{ }^{\circ} \mathrm{C}$ can be atributed to boiling of carvacrol [13].

\subsection{Release kinetics}

For the investigation of carvacrol release kinetics, physiological saline solution was used as the release medium in order to simulate the body fluids. Cumulative release of carvacrol from the impregnated CA film (31.4\% of carvacrol) is presented in Figure 5. As can be seen, the film released almost $85 \%$ and $88 \%$ of the impregnated carvacrol after $360 \mathrm{~min}$ and $24 \mathrm{~h}$, respectively. Bearing in mind that one of the possible applications of CA films impregnated with carvacrol is for wound dressings, a controlled release of carvacrol during short time intervals would be desirable in order to prevent infections.

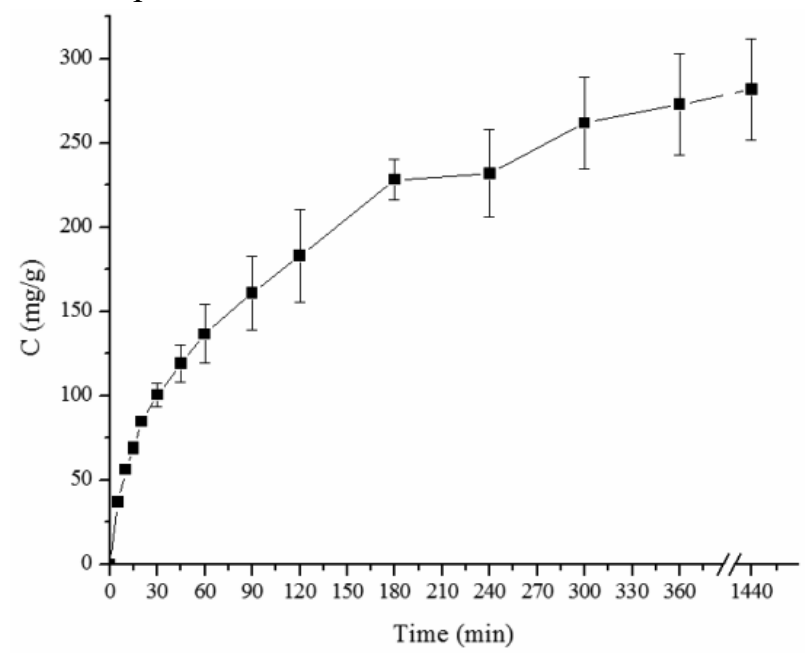

Figure 5 - Cumulative release of carvacrol from impregnated CA films (31.4\%)

Release kinetics of carvacrol from the impregnated CA film was examined by fitting with the Korsmeyer-Peppas, first order and Higuchy mathematical models (Table 1). Modeling analysis was performed for the period of time until $60 \%$ of carvacrol was released. Table 1 revealed that the Higuchi model fits the best the release profiles of carvacrol. These results implied that the release of carvacrol was governed by the diffusion which controlled the processes. The absence of a significant number of pores on the impregnated CA film's surface (Figure 3c) would explain the phenomenon that the release of the active component was controlled by the diffusion rather than by the capillarity mechanism of this film [1]. The obtained results (Table 1) are in the accordance with the literature since the Higuchi model is widely used in a description of diffusion controlled release from transdermal systems [22, 23]. Table 1 also reveals that the Korsmeyer-Peppas release exponent $n$ is above 0.43 indicating that the carvacrol release occurred by anomalous non-Fickan transport. Bierhalz et al. suggested that natamicin release from the alginate film was in accordance with the Fickan diffusion [24]. Milovanovic et al. [19] also showed that the mechanisms of release of thymol from CA beads followed Fickan and non-Fickan diffusion depending on the thymol impregnation yields as well as the release medium.

Table 1. Correlation coefficients $\left(R^{2}\right)$, release exponent, and release constants of models used for description of the carvacrol release mechanism

\begin{tabular}{|l|l|}
\hline Korsmeyer-Peppas & \\
\hline$k \times 10^{-2}, \mathrm{~min}^{-\mathrm{n}}$ & 6.46 \\
\hline$n$ & 0.49 \\
\hline $\mathrm{R}^{2}$ & 0.991 \\
\hline First order & \\
\hline$k \times 10^{-3}, \mathrm{~min}^{-1}$ & 9.83 \\
\hline $\mathrm{R}^{2}$ & 0.951 \\
\hline Higuchi & \\
\hline$k \times 10^{-2}, \min ^{1 / 2}$ & 6.15 \\
\hline $\mathrm{R}^{2}$ & 0.998 \\
\hline
\end{tabular}

The antibacterial activity of carvacrol has been already analyzed in many studies [9-13]. Carvacrol's hydrophobic nature as well as its free hydroxyl function are two main factors responsible for its antibcterial nature [12]. Considering the release kinetics of carvacrol from the CA films and its proven antimicrobial activity, we can suppose that the obtained films have a potential for treatment of topical infections and in prevention of food spoilage.

\section{CONCLUSION}

Cellulose acetate films were successfully produced by the solvent casting method and subsequently impregnated with carvacrol using supercritical carbon dioxide at $21 \mathrm{MPa}$ and $50 \mathrm{C}$. It was estimated that the increase in impregnation time from $30 \mathrm{~min}$ to $120 \mathrm{~min}$ led to an increase in the carvacrol impregnation yield, while the increase in decompression spead from 0.3 to $36 \mathrm{MPa} / \mathrm{min}$ decreased the carvacrol impregnation yield.

The CA film with $31.4 \%$ of impregnated carvcrol released almost $90 \%$ of carvacrol within $24 \mathrm{~h}$. In addition, the controlled release of carvacrol from the CA film was obtained. The Higuchi and KorsmeyerPeppas models fitted the carvacrol release curve well. The obtained carvacrol impregnated CA films have a prospective for application in medicine as wound dressings considering their biocompatibility and biodegradability as well as their potential antimicrobial activity or in the food industry as an active food packaging. Further studies are needed in these directions. 


\section{ACKNOWLEDGMENT}

Financial support of the Serbian Ministry of Education, Science and Technological Development (Project No. III 45017) is gratefully acknowledged.

\section{REMARK}

The paper was presented at the 16th Young researchers' conference, Materials science and engineering, Belgrade, December 6-8, 2017.

\section{REFERENCES}

[1] Rodríguez F. J, Galotto M. J, Guarda A, Bruna J. E, Modification of cellulose acetate films using nanofillers based on organoclays, Journal of Food Engineering, Vol. 110, pp. 262-268, 2012.

[2] Medina-Gonzalez Y, Camy S, Condoret J. S, Cellulosic materials as biopolymers and supercritical $\mathrm{CO} 2$ as a green process: chemistry and applications, International Journal of Sustainable Engineering, Vol. 5, No. 1, pp. 47-65, 2012.

[3] Yuan J, Shang P. P, Wu S. H, Effects of polyethylene glycol on morphology, thermomechanical properties, and water vapor permeability of cellulose acetate-free films, Pharm. Technol., Vol. 25, No. 10, pp. 62-73, 2001.

[4] Liakos I, Rizzello L, Hajiali H, Brunetti V, Carzino R, Pompa PP, Athanassiou A, Mele E, Fibrous wound dressings encapsulating essential oils as natural antimicrobial agents, Journal of Materials Chemistry B, Vol. 3, pp. 1583-1589, 2015.

[5] Liakos I. L, Holban A. M, Carzino R, Lauciello S, Grumezescu A. M, Electrospun fiber pads of cellulose acetate and essential oils with antimicrobial activity, Nanomaterials, Vol. 84, No. 7, pp. 1-10, 2017.

[6] Gouvea D. M, Mendonca R. C. S, Soto M. L, Cruz R. S, Acetate cellulose film with bacteriophages for potential antimicrobial use in food packaging, $L W T$ Food Science and Technology, Vol. 63, pp. 85-91, 2015.

[7] Soares N. F. F, Hotchkiss J. H, Bitterness reduction in grapefruit juice through active packaging, $P a$ ckaging Technology and Science, Vol. 11, pp. 9-18, 1998.

[8] Mišić D, Zizovic I, Stamenić M, Ašanin R, Ristić M, Petrović S. D, Skala D, Antimicrobial activity of celery fruit isolates and SFE process modeling, Biochemical Engineering Journal, Vol. 42, No. 2, pp. 148152, 2008.

[9] Liolios C. C, Gortzi O, Lalas S, Tsaknis J, Chinou I, Liposomal incorporation of carvacrol and thymol isolated from the essential oil of Origanum dictamnus L. and in vitro antimicrobial activity, Food Chemistry, Vol. 112, pp. 77-83, 2009.

[10]Milovanovic S, Adamovic T, Aksentijevic K, Misic D, Ivanovic J, Zizovic I, Cellulose acetate based material with antibacterial properties created by supercritical solvent impregnation, International Journal of Polymer Science, Vol. 2017, Article ID 8762649, 9 pages, https://doi.org/10.1155/2017/8762649

[11]Gunal M. Y, Heper A. O, Zaloglu N, The effects of topical carvacrol application on wound healing process in male rats, PHCOG J, Vol. 6, No. 3, pp. 1014, 2014.

[12]Lavoine N, Givord C, Tabary N, Desloges I, Martel B, Bras J, Elaboration of a new antibacterial bionano-material for food-packaging by synergistic action of cyclodextrin and microfibrillated cellulose, Innovative Food Science and Emerging Technologies, Vol. 26, pp. 330-340, 2014.

[13]Kamimura J. A, Santos E. H, Hill L. E, Gomes C. L, Antimicrobial and antioxidant activities of carvacrol microencapsulated in hydroxypropyl-beta-cyclodextrin, LWT - Food Science and Technology, Vol. 57, 701-709, 2014.

[14]Kikic I, Vecchione F, Supercritical impregnation of polymers, Current Opinion in Solid \& Material Science, Vol. 7, pp. 399-405, 2003.

[15]Kazarian S. G. Polymer processing with supercritical fluids, Polymer Science, Ser. C, Vol. 42, No. 1, pp. 78-101, 2000.

[16]Milovanovic S, Stamenic M, Markovic D, Radetic M, Zizovic I, Solubility of thymol in supercritical carbon dioxide and its impregnation on cotton gauze, J. of Supercritical Fluids, Vol. 84, pp. 173-181, 2013.

[17]Varonaa S, Rodríguez-Rojo S, Martín A, José Cocero M, Duarte CMM. Supercritical impregnation of lavandin (Lavandula hybrida) essential oil in modified starch, J. of Supercritical Fluids, Vol. 58, pp. 313-319, 2011.

[18]Champeau M, Supercritical CO2 assisted impregnation to prepare drug-eluting implante, $\mathrm{PhD}$ Thesys, Universite de Bordeaux, Université de Liège, 2014.

[19]Milovanovic S, Markovic D, Aksentijevic K, Stojanovic D. B, Ivanovic J, Zizovic I, Application of cellulose acetate for controlled release of thymol, Carbohydrate Polymers, Vol. 147, pp. 344-353, 2016. 
[20]Shen Z, Huvard G. S, Warriner S, Mc Hug M, Banyasz J. L, Mishra M. K, $\mathrm{CO}_{2}$-assisted fiber impregnation. Polymer, Vol. 49, No. 6, pp. 1579-1586, 2008.

[21]Wongsasulak S, Tongsin P, Intasanta N, Yoovidhya T. Effect of glycerol on solution properties governing morphology, glass transition temperature, and tensile properties of electrospun zein film, Journal of Applied Polymer Science, Vol. 118, pp. 910-919, 2010.

[22]Higuchi T, Mechanism of sustained-action medication- theoretical analysis of rate of release of solid drugs dispersed in solid matrices, J. Pharm. Sci.-US, Vol. 52, pp. 1145-1149, 1963.

[23] Costa P, Lobo J. M. S, Modeling and comparison of dissolution profiles, Eur. J. Pharm. Sci., Vol. 13, pp. 123-133, 2001.

[24]Bierhalz A. C. K, da Silva M. A, de Sousa H. C, Braga M. E. M, Kieckbusch T. G, Influence of natamycin loading methods on the physical characteristics of alginate active films, J. Supercrit. Fluid, Vol. 76, pp. 74-82, 2013.

\section{REZIME}

\section{IMPREGNACIJA FILMOVA ACETATA CELULOZE KARVAKROLOM POMOĆU NATKRITIČNOG UGLJENIK(IV)-OKSIDA}

Filmovi acetata celuloze su impregnirani karvakrolom pomoću natkritičnog ugljenik(IV)-oksida. Proces natkritične impregnacije, izveden u statičkom režimu na pritisku $21 \mathrm{MPa}$ i temperaturi $50{ }^{\circ} \mathrm{C}$, je optimizovan varijacijom procesnog vremena (30 i $120 \mathrm{~min}$ ) $i$ brzine dekompresije (od 0,3 MPa/min do 36 MPa/min). Karakterizacija dobijenih filmova acetata celuloze je izvedena pomoću mikroskopije atomskih sila i diferencijalne skenirajuće kalorimetrije. Efekat glicerola i karvakrola na karakteristike dobijenih filmova je objašnjen. Otpuštanje karvakrola iz filma koji je ima 31,4\% primos impregnacije karvakrola je ispitano u fiziološkom rastvoru. Dodatno, Higuči i Korsmejer-Pepas modeli otpuštanja su dobro fitovali krivu otpuštanja karvakrola. Dobijeni filmovi acetata celuloze impregnirani karvakrolom mogu biti značajni za primenu u medicini za previjanje rana uzimajući u obzir njihovu biokompatibilnost i biodegradabilnost kao i potencijalno antimikrobno dejstvo ili u industriji hrane kao aktivno pakovanje. Ključne reči: karvakrol, film acetata celuloze, natkritični ugljenik(IV)-oksid, natkritična impregnacija 